\title{
“Facial Idiopathic Granulomas with Regressive Evolution, is Lupus Miliar Diseminatus Faciae a Synonymous?"
}

\author{
Aldás EG ${ }^{1 *}$, Donoso GT² ${ }^{2}$ Garzón $\mathrm{X}^{3}$ and Escalante $\mathrm{L}^{4}$ \\ ${ }^{1}$ Dermatologist in Clínica Dermatológica, San Rafael, Ecuador, USA \\ ${ }^{2}$ Dermatologist in DAI-MED, San Rafael, Ecuador, USA \\ ${ }^{3}$ Medical resident in Clínica Dermatológica, San Rafael, Ecuador, USA \\ ${ }^{4}$ Medical Resident in Carlos Andrade Marin Hospital, San Rafael, Ecuador, USA
}

\section{Case Report \\ Volume 2 Issue 1}

Received Date: December 30, 2016

Published Date: January 31, 2017

DOI: $10.23880 /$ cdoaj16000110

*Corresponding author: Eduardo Garzón Aldás, Dermatologist in Clínica Dermatológica, Avenida Ilaló y Farina esquina, Edif. Mariana de Jésus. Piso \# 3, San Rafael, Ecuador, USA, Tel: 0984947330; E-mail: eduderma@hotmail.com

\section{Abstract}

Disseminated lupus miliary of the face (DLMF) has been reported infrequently at the time that has received multiple denominations. It is clinically characterized by brown erythematous monomorphic papules of between 1 to 4 millimeters in diameter and icepick scars like acne.

The cases presented in this document show the variability of presentation and manifestation of this pathology, the same that in certain occasions coincides with the previous reports, but also exist in others pathologists with a different presentation.

Treatment with corticosteroids has shown improvement in lesions, coinciding with the reported literature.

Keywords: Lupus miliar disseminatus faciae; Acne agminata; Perioral granulomatous dermatitis; Facial idiopathic granulomas

\section{Introduction}

Disseminated lupus miliary of the face (DLMF) was first described in 1903, and has been a pathology reported infrequently in the medical literature. It has received different names over time: micro-apical tuberculids [1-4], acne agminata [5-7], rosacea lupoid [6,8-10], names that has been related with these conditions, and with the passage of time, it has been losing its livelihood of association. After several clinical, histopathological and evolutionary observations, several authors have proposed the name of the Anglo-Saxon acronym FIGURE (facial idiopathic granulomas with regressive evolution), which in Spanish would be: idiopathic facial granulomas with regressive evolution [1,11-13].
It is clinically characterized by an eruption of brownish erythematous monomorphic papules between from 1 to 4 millimeters in diameter, which can develop into pustules, mainly located in the central part of the face, with frequent involvement of the palpebral area [14]. The pathology presentation produces an auto involution, which heal leaving hyperpigmented scars on ice pick similar to those of acne $[13,15]$.

There are seven patients affected by this pathology in them we have found the clinical histopathological characteristics described in the literature, but also a hyperkeratotic component not previously reported. 


\section{Clinical Cases}

We report seven patients, five young adults and two pediatric patients (Table 1), all of them had a chronic papular eruption with no apparent cause. The papules were monomorphic, numerous, non-confluent, erythematous-brown, with diameters between 2 to 6 millimeters, dome-shaped, some with smooth and shiny surface and others with hyperkeratotic centers, distributed bilaterally and symmetrically on cheeks, nasogenic furrows, eyelids (Figure $1 \mathrm{~A}$ and $\mathrm{B}$ ) as well as in the nose, central area of the forehead, and in the perioral area. The lesions were not accompanied by other cutaneous or systemic signs or symptoms and led to patients being consulted for the progressive appearance in both of them numbers and size, as well as the lack of response to previous treatments for various topical and oral medications which contained broad spectrum antibiotics and mainly retinoid. In the clinical history, patients mentioned the regression of some lesions, leaving scars like ice-pick in some places.
No patient have showed alterations in blood exams, blood chemistry, angiotensin-converting enzyme levels, HIV serology, elemental and microscopic urine exam, chest X-ray, acid-fast bacillus acid study of sputum and urine. The PPD skin tests showed different values ranging from 0 to 4 millimeters (Table 1 ).

We performed 4-mm punch biopsy for hematoxylineosin, PAS, Giemsa, Zhiel-Nellsen, Grocott and Dimethylene blue test stains (Table 2). The findings were dominated by granulomatous inflammatory infiltrate of perifollicular predominance with epithelial cells, giant cells, lymphocytes, absence of caseous necrosis, some dilated follicles with keratinous content and no microorganisms were identified nor presence of mucin (Figure 2A-C).

The treatment used in all of them was oral prednisone doses at $1 \mathrm{mg} / \mathrm{kg} /$ day and $500 \mathrm{mg}$ oral tetracycline twice daily used in adults, and topical erythromycin $4 \%$ solution in pediatric patients, with an adequate evolution in an average of 16 weeks.

\begin{tabular}{|c|c|c|c|c|c|c|c|c|c|}
\hline Patient & Sex & Age & $\begin{array}{c}\text { Evolution } \\
\text { Time }\end{array}$ & $\begin{array}{c}\text { Periocular, } \\
\text { Perioral and } \\
\text { Nasal Injuries }\end{array}$ & $\begin{array}{c}\text { Icepick } \\
\text { Scars }\end{array}$ & $\begin{array}{c}\text { Papular } \\
\text { Keratosic } \\
\text { Injuries }\end{array}$ & $\begin{array}{c}\text { CBC, CMP, } \\
\text { chest X- } \\
\text { ray }\end{array}$ & $\begin{array}{c}\text { BAAR, } \\
\text { Urine, } \\
\text { Sputum }\end{array}$ & PPD \\
\hline 1 & M & 24 YEARS & 2 YEARS & YES & YES & YES & N & Neg & $4 \mathrm{~mm}$ \\
\hline 2 & F & 25 YEARS & 1YEAR & YES & YES & YES & N & Neg & $3 \mathrm{~mm}$ \\
\hline 3 & M & 30 YEARS & 6 MONTHS & YES & YES & YES & N & Neg & $0 \mathrm{~mm}$ \\
\hline 4 & M & 5 YEARS & 1 YEAR & YES & YES & No & N & Neg & $4 \mathrm{~mm}$ \\
\hline 5 & F & 19 YEARS & 5 MONTHS & YES & YES & YES & N & Neg & $5 \mathrm{~mm}$ \\
\hline 6 & M & 28 YEARS & 1 YEAR & YES & YES & No & N & Neg & $3 \mathrm{~mm}$ \\
\hline 7 & F & 4 YEARS & 6 MONTHS & YES & No & YES & N & Neg & $2 \mathrm{~mm}$ \\
\hline
\end{tabular}

Table 1: Demographic, clinic and laboratory data.

CBC: Complete Blood Count; CMP: Comprehensive Metabolic Panel; F: Female; M: Male; N: Normal; Neg: Negative.

\begin{tabular}{|c|c|c|c|c|c|c|c|c|c|}
\hline Patient & $\begin{array}{l}\text { Peripheral } \\
\text { granulomas }\end{array}$ & $\begin{array}{c}\text { Surface } \\
\text { dermal } \\
\text { granulo } \\
\text { mas }\end{array}$ & $\begin{array}{l}\text { Epithelioid } \\
\text { cells }\end{array}$ & $\begin{array}{l}\text { Giant } \\
\text { cells }\end{array}$ & $\begin{array}{l}\text { Lympho } \\
\text { cytes }\end{array}$ & $\begin{array}{l}\text { Caseous } \\
\text { necrosis }\end{array}$ & $\begin{array}{c}\text { Dilated } \\
\text { hair } \\
\text { follicles }\end{array}$ & $\begin{array}{c}\text { Intrafollic } \\
\text { ular } \\
\text { keratin }\end{array}$ & Stain \\
\hline 1 & $+++/+++$ & $++/+++$ & $+++/+++$ & $+++/+++$ & $+/+++$ & - & $+/+++$ & $+/+++$ & $\mathrm{N}$ \\
\hline 2 & $++/+++$ & $+/+++$ & $+++/+++$ & $+++/+++$ & $++/+++$ & $+/+++$ & $+/+++$ & $+/+++$ & $\mathrm{N}$ \\
\hline 3 & $++/+++$ & $++/+++$ & $++/+++$ & $+++/+++$ & $+++/+++$ & - & - & - & $\mathrm{N}$ \\
\hline 4 & $+/+++$ & $++/+++$ & $++/+++$ & $++/+++$ & $++/+++$ & - & $+/+++$ & $+/+++$ & $\mathrm{N}$ \\
\hline 5 & $+++/+++$ & $+/+++$ & $+++/+++$ & $+++/+++$ & $+/+++$ & - & $+++/+++$ & $+++/+++$ & $\mathrm{N}$ \\
\hline 6 & $+++/+++$ & $++/+++$ & $+++/+++$ & $+++/+++$ & $+/+++$ & - & $+++/+++$ & $+++/+++$ & $\mathrm{N}$ \\
\hline 7 & $++/+++$ & $++/+++$ & $++/+++$ & $++/+++$ & $+/+++$ & - & - & - & $\mathrm{N}$ \\
\hline
\end{tabular}

Table 2: Histopathology characteristics.

$(+)$ : Present; $(-)$ : Absent; $(+/+++)$ : Scarce in the field at the least increase; $(++/+++)$ : Moderate at the lowest field; $(+++/++)$ : Numerous in the field at the least increase; $(\mathrm{N})$ : Did not show microorganisms or mucin. 


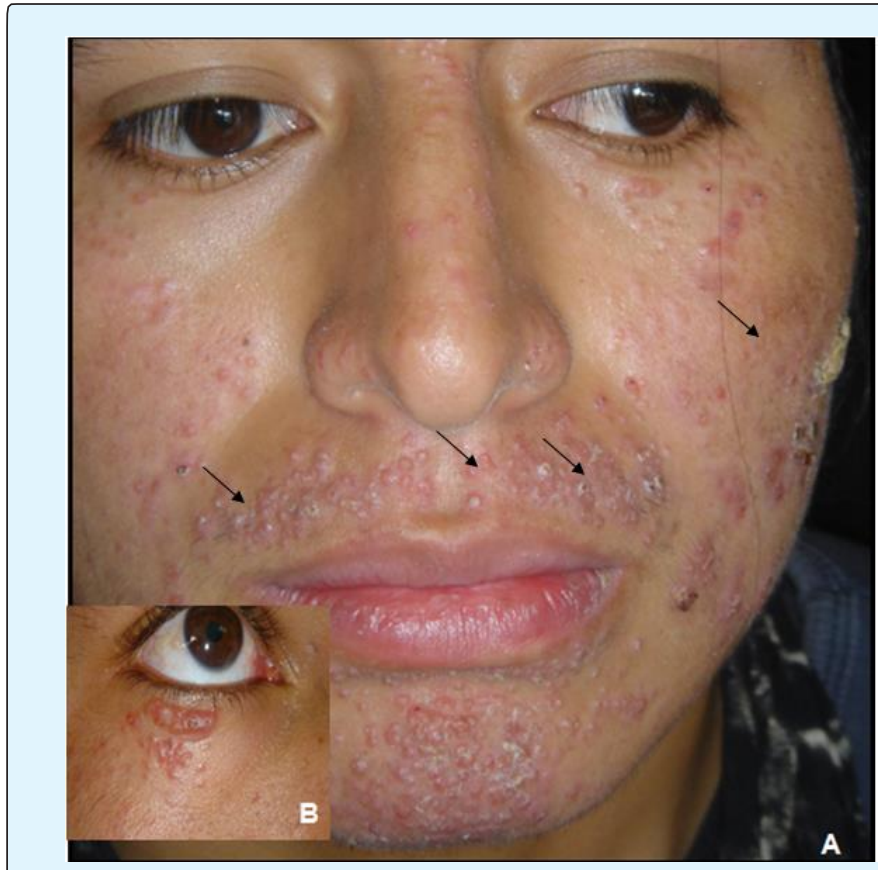

Figure 1: A) Predominal periorificial monomorphic injury, look on the left cheek a large keratotic lesion and some papules with a hyperkeratosis center on the upper lip,

B) Approximation of the periocular lesions, in which different evolutionary stages (skin-colored papules are clearly seen, later to become erythematous, to increase its infiltration, and to finish some with keratotic component).

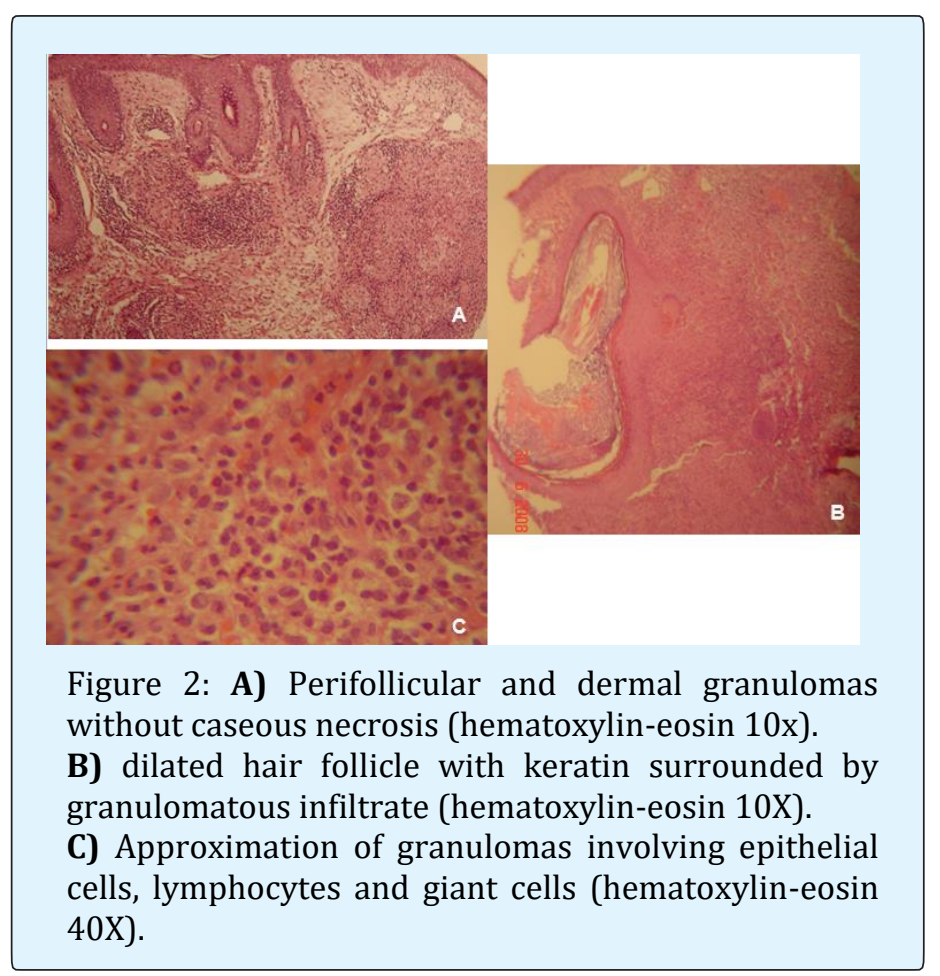

\section{Commentary}

Disseminated lupus miliary of the face (DLMF) was first described in 1903 as an eruption consisting of groups of brownish-reddish papules, which may evolve to pustules, and which show a tendency to spontaneous involution leaving punctiform pigmented scars $[16,5]$.

Initially, it was considered a variant of lupus vulgaris or a tuberculid lesion, since the histological characteristics showed a granulomatous inflammatory infiltrate with caseous necrosis [6]. However, there has been no evidence to date that supports the link with tuberculosis. Although, the histopathology may be compatible, the clinical course is self-limited, with no recurrence, no other foci, poor or no response to tuberculostatic, negative of the Mantoux intradermal reaction in most cases and the negativity of the PCR studies allow it to be ruled out [2]. Consequently, the terms acne agminata, and idiopathic facial granuloma with regressive evolution have replaced the term "disseminated lupus miliary of the face" in several parts of the world. However, this condition is not a variant of acne and does not always occur as repetitive outbreaks of injury, so the name acne agminata is also not appropriate [17-19]. It is important to bear in mind that what has led to this denomination are certain similarities with acne, such as the predominance of lesions in the central facial area, and even in extra facial areas like sebaceous glands in thorax, also the coexistence in many cases of pustular lesions and later scars ice pick like [19]. I should mention that if some type of acne could be confused, especially in the initial stages, it will be with the steroid-type medication acne, due to its relation with monomorphic lesions. The acronym proposed in recent years of "FIGURE" (facial idiopathic granuloma with regressive evolution) is the most appropriate, since in addition to avoiding the link connection with acne or tuberculosis that defines the clinical, etiological and evolutionary aspects of this controversial and uncommon pathology [6]. Although the term "disseminated lupus miliary of the face" is the most well-known and widespread, it should begin to be reconsidered and changed. A short time ago this pathology was conceived as a granulomatous or lupoid rosacea because relationship of granulomas with the pilosebaceous units because it common found epithelial granulomas in patient with rosacea $^{6}$, however, the clinical characteristics are different, the disseminated lupus miliary of the face does not show a hyperreactivity of the facial vasculature, no erythema, and it does not worsen with caloric, solar, alcohol or spicy food stimuli and no telangiectases [1416]. Many authors have also related this dermatosis with 
sarcoidosis in special with the maculopapular presentation, but the absence of systemic compromise, normal angiotensin-converting enzyme levels, lack of compromising of old scars, and finally the autoimmune behavior with punctate residual scar of the facial idiopathic granuloma with regressive evolution discard their linkage. We must include in this analysis two entities that, due to their clinical and histology similarity to the pathology mentioned, should be taken into this account, the first one is the perioral granulomatous dermatitis and the second one is the Afro-Caribbean facial eruption of childhood (FACE) [15], which in recent years have been grouped under the name of periorificial granulomatous dermatitis [3]. I want to mention that all our patients, adults and children, kept the clinical characteristics described in the controversial pathologies (DLMF or acne agminata, periorificial granulomatous dermatitis), namely chronic facial eruption, with special involvement of the periocular and perioral skin, with different evolutionary stages, while some papules appeared, some evolve to pustules and others to central hyperkeratosis, and others involved leaving hyperpigmented scars in ice pick like [20]. The majority patients (5/7) presented a characteristic not described in the previous bibliographical reports and correlated with the histology as the hyperkeratotic component. Only in one of the seven, the histology could be considered as caseous necrosis with granulomas tuberculoid like, but even in this patient, no clinical or laboratory data were identified that could link it to tuberculosis. In all patients, the histology corresponded a granulomatous dermatitis with perifollicular predominance, in which the dominate cells were epitheloid and giant like [19]. All patients had an adequate response to prednisone, coinciding with the literature reported, an additional reason to realize that this pathology is not related to tuberculosis, nor rosacea, because the patients had worsened [13]. For all the above mentioned, we agree with other authors in what was formerly called and considered as different pathologies like Disseminated lupus miliary of the face, acne agminata, and periorifical granulomatous dermatitis, all should be considered as a single pathology with different evolutionary aspects, and histological stages, under the term Idiopathic Facial Granulomas with regressive evolution [18].

\section{Conclusion}

The clinical entity exposed on this paper, is infrequent and often under diagnosed, confused mainly with periorificial dermatitis of adult and childhood, and has been named over time with multiple terms, however after exposing its clinical and histopathological characteristics, we agree with other authors to denominate it with the term FIGURE (facial idiopathic granulomas with regressive evolution). It is important to keep in mind, that a diagnostic clinical clue is the presence of the follicular hyperkeratotic component, which disappear leaving icepick scars; also it is evident that the histopathology clearly marks the definitive diagnosis.

\section{References}

1. Laymon CW, Michelson HE (1940) The micropapular tuberculid: Arch Dermatol Syphilol 42(4): 625-640.

2. Mullanax MG, Kierland R (1970) Granulomatous rosacea. Arch Dermatol 101(2): 206-211.

3. Moloney FJ, Egan CA (2003) Acne agminata (lupus miliaris disseminates faciei). Clin Exp Dermatol 28(6): 685-686.

4. Crawford GH, Pelle MT, James WD (2004) Rosacea: I. Etiology, pathogenesis and subtype classification. J Am Acad Dermatol 51(3): 327-341.

5. Scott KW, Calnan CD (1967) Acne agminata. Trans St John's Hosp Dermatol Soc 53(1): 60-69.

6. Michelson HE (1958) Does the rosacea-like tuberculid of Lewandowsky exist? Arch Dermatol Syphilol 78(6): 681-688.

7. Hillen U, Schröter S, Denisjuk N, Jansen T, Grabbe S (2006) Axillary acne agminata (lupus miliaris disseminatus faciei with axillary involvement). J Dtsch Dermatol Ges 4(10): 858-860.

8. Naranjo R, Armijo-Moreno M, Camacho F, Herrera E, Armijo-Lozano R (1977) Lewandowsky's syndrome (rosacea lupoide). Apropos of 11 cases. Actas DermoSifiliográficas 68(9-10): 525-536.

9. El Darouti M, Zaher H (1993) Lupus miliaris disseminatus faciei: pathologic study of early, fully developed, and late lesions. Int J Dermatol 32(7): 508511.

10. English JC, Patel PJ, Creer KE (2001) Sarcoidosis. J Am Acad Dermatol 44(5): 725-746.

11. Skowron F, Causeret AS, Pabion C, Viallard AM, Balme B, Thomas L (2000) FIGURE.. Facial idiopathic granulomas with regressive evolution. is 'lupus 


\section{Clinical Dermatology Open Access Journal}

miliaris disseminatus faciei' still an acceptable diagnosis in the third millennium?. Dermatology 201(4): 287-289.

12. Bedlow AJ, Otter M, Marsden RA (1998) Axillary acne agminata (lupus miliaris disseminatus faciei). Clin Exp Dermatol 23(3): 125-128.

13. Botella R, Castejón P, Sanmartín O, Arnedo L, Guillén C (1998). Lupus miliaris disseminatus faciei: an uncommon form of rosacea. Actas Dermosifiliogr 89(6): 321-324.

14. Nino M, Barberio E, Delfino M (2003) Lupus miliaris disseminatus faciei and its debated link to tuberculosis. J Eur Acad Dermatol Venereol 17(1): 97.

15. Shitara A (1984) Lupus miliaris disseminatus faciei. Int J Dermatol 23(8): 542-544.

16. Van de Scheur M, Van der Waal RI, Starink TM. (2003). Lupus miliaris disseminatus faciei: a distinctive rosacea-like syndrome and not a granulomatous form of rosacea. Dermatology 206(2): 120-123.
17. Alonso V, Ramóna D, Martína JM, Monteagudob C, Molinaa I, et al. (2005) Miliary lupus disseminated from the face. Actas Dermosifiliogr 96(3): 182-185.

18. Helm KF, Menz J, Gibson LE, Dicken CH (1991) A clinical and histopathologic study of granulomatous rosacea. J Am Acad Dermatol 25(6): 1038-1043.

19. Williams HC, Ashworth J, Pembroke AC, Breathnach SM (1990) FACE- facial Afro-Caribean childhood eruption. Clin Exp Dermatol 15(3): 163-166.

20. Hodak E, Trattner A, Feuerman H, Feinmesser M, Tsvieli R, et al. (1997) Lupus miliaris disseminates faciei- the DNA of Mycobacterium tuberculosis is not detectable in active lesions by polymerase chain reaction. Br J Dermatol 137(4): 614-619. 